\title{
Effect of Paracetamol in the Proliferation of Glioblastoma Cell Line: The Role of Apoptosis, COX-2 and Cyclin B Expressions
}

\author{
Ersoy OKSUZ1', Gokhan GORGISEN², Hulya OZDEMIR', Ismail Musab GULACAR², Gokhan OTO' \\ ${ }^{1}$ Van Yuzuncu YII University, School of Medicine, Department of Medical Pharmacology, Van, Turkey \\ ${ }^{2}$ Van Yuzuncu YIl University, School of Medicine, Department of Medical Biology, Van, Turkey \\ Corresponding author: Ersoy OKSUZ drugoksuz@hotmail.com
}

\section{ABSTRACT}

AIM: To investigate the relationship between paracetamol and expression levels of cyclooxygenase-2, cyclin B, cell viability and apoptosis in glioblastoma cell line.

MATERIAL and METHODS: The A172 glioblastoma cells were treated with different concentrations of paracetamol and phosphate buffer saline as a vehicle for 24,48 , and $72 \mathrm{~h}$. Cell viability was detected by MTT. Bax, procaspase 3 , COX-2 and Cyclin B expressions were detected using Western blotting.

RESULTS: A paracetamol treatment of $0.5 \mathrm{mg} / \mathrm{mL}$ for 24,48 , and 72 hours led to a $14 \%, 31 \%$, and $37 \%$ decrease in cell viability. The expression of COX-2 and cyclin B levels decreased by $36 \%$ and $52 \%$ respectively, after treatment with $0.5 \mathrm{mg} / \mathrm{mL}$ paracetamol. Treatment with $0.5 \mathrm{mg} / \mathrm{mL}$ and $1 \mathrm{mg} / \mathrm{mL}$ paracetamol significantly induced the expression of cleaved caspase 3 , procaspase 3 and Bax proteins compared to the control group (60\%, 40\%, 21\%, \%100, 18\%, 17\%, respectively).

CONCLUSION: The results of our study showed that paracetamol has antitumoral effects on glioblastoma cells and this activity was induced by different signaling pathways.

KEYWORDS: Paracetamol, Glioblastoma, COX-2, Cyclin B, Apoptosis

\section{INTRODUCTION}

\footnotetext{
$\checkmark$
} lioblastoma is the most common primary brain tumor and is also classified as grade IV astrocytoma. It is commonly seen with uncontrolled cell proliferation, increased angiogenesis, local invasion of tissue, resistance to apoptosis, and a heterogenic genetic background. The average life expectancy of a patient with glioblastoma is usually 12-15 months, even if the patient undergoes surgery, chemotherapy, and radiotherapy $(7,11)$. Therefore, developing new treatment options and revealing the molecular mechanisms that play a role in the formation of glioblastoma is very important.

Cyclooxygenase enzymes produce prostaglandins from arachidonic acid. Inducible cyclooxygenase-2 (COX-2) enzyme, which can be induced by various factors, has been shown to increase in many tumors, such as colorectal, pancreas, and lung. An increase in cell proliferation and progression and decrease in apoptosis directly correlated with the COX2 expression level has been observed in many tumors (23). Prostaglandin E2 (PGE2), a product of the COX enzyme, is responsible for these effects of COX-2 on tumors. PGE2 is associated with various intracellular signaling pathways, such as phosphoinositide-3-kinase (PI3K/Akt), protein kinase $A$, mitogen-activated protein kinase (MAPK) $(17,22)$. Therefore, nonsteroidal anti-inflammatory drugs (NSAIDs), which are both selective COX-2 inhibitors and non-selective COX inhibitors have been seen as potential anticancer drugs, and these drugs have been shown to reduce proliferation in tumor cells, increase apoptosis, and reduce invasion and angiogenesis in many studies (13). However, many studies have suggested that NSAIDs have antitumorigenic effects, which have inde-
Ersoy OKSUZ (10: 0000-0002-8088-1009

Gokhan GORGISEN (1) : 0000-0001-6040-7863

Hulya OZDEMIR (1): 0000-0002-6045-8342
Ismail Musab GULACAR (1) : 0000-0002-9431-5585

Gokhan OTO (1) : 0000-0001-7310-7800 
pendent mechanisms, unlike COX-2 and PGE2. For example, diclofenac has been shown to cause the phosphorylation of signal transductions and activators (STAT-3) in glioblastoma cells and stop the cells at the G2/M phase (12). Similarly, celecoxib has been found inhibit the p53-dependent G1 cell cycle arrest and autophagy in glioblastoma cells (10).

Paracetamol is widely used as an analgesic and antipyretic agent throughout the world (8). Paracetamol inhibits COX enzyme activity, like NSAIDs, and there are many studies that have shown the anticancer properties of paracetamol. For example, paracetamol induced c-Jun-terminal kinase (JNK) in human mesenchymal cell culture, and nuclear factor kappa B (NFkB) activation in human neuroblastoma cell culture (24). Paracetamol triggered the apoptotic signaling pathways via the induction of caspase-3 activity and increased DNA fragmentation and caused apoptosis in the study of hepatocyte cell culture (3).

In this study, we aimed to investigate the relationship between COX-2, cyclin B expression levels, cell viability and apoptosis in glioblastoma cells.

\section{MATERIAL and METHODS}

\section{Cell Culture}

A172 cells, a human glioblastoma cell line, was cultured in Dulbecco's modified Eagle's medium supplemented with $50 \mathrm{mg} / \mathrm{mL}$ streptomycin, $100 \mathrm{mg} / \mathrm{mL}$ penicillin, and $1 \mathrm{mM}$ L-glutamine.

\section{Cell Viability Test: MTT}

A172 cells were plated at 5000 cells/well in 96 well plates with 6 replicates. After overnight incubation, the cells were treated with different concentrations $(0,0.1,0.2,0.5,1,3$, 4,7 , and $9 \mathrm{mg} / \mathrm{mL}$ ) of paracetamol (paracerol $10 \mathrm{mg} / \mathrm{mL}$ I.V polipharma) and phosphate buffer saline (PBS) as a vehicle for 24,48 , and 72 hours (h). At the end of the incubation, $5 \mathrm{mg} /$ $\mathrm{mL}$ of MTT solution was added to each well for $4 \mathrm{~h}$ at $37^{\circ} \mathrm{C}$ in an incubator. Next, the medium was removed and formazan crystals were dissolved in DMSO $(100 \mu \mathrm{L})$. The amount of MTT formazan product formed was determined by measuring the absorbance (A) at $540 \mathrm{~nm}$, with $690 \mathrm{~nm}$ as the reference wavelength.

\section{Western Blotting}

The control and treated cells were lysed in Triton X-100 buffer containing $1 \mathrm{mM}$ sodium orthovanadate, $1 \mathrm{mM}$ PMSF, 0.15 units $/ \mathrm{mL}$ aprotinin, $10 \mu \mathrm{g} / \mathrm{mL}$ leupeptin, and $10 \mu \mathrm{g} / \mathrm{mL}$ pepstatin A. For the western blot analysis, $75 \mathrm{mcg}$ of protein was fractionated by sodium dodecyl sulfate polyacrylamide gel electrophoresis (SDS-PAGE), and then transferred to the PVDF membranes. The membranes were blocked in 5\% skim milk powder in PBST. The blots were labeled with Bax, Caspase 3, COX-2 and Cyclin B antibodies. Beta actin was used as a loading control. The signal intensity on the blots was determined using the enhanced chemiluminescent detection system.

\section{Statistical Analysis}

Data were evaluated using the Microsoft Excel and SPSS programs. The test $P$ value results were calculated using Oneway ANOVA (Dunnet t-test). Results are shown as normalizing and \pm determined standard error values.

\section{RESULTS}

\section{The Effect of Paracetamol on Cell Viability}

After treatment with 0.1 and $0.2 \mathrm{mg} / \mathrm{mL}$ of paracetamol for 24 $h$, no changes in the cell viability was observed, whereas the rate of cell viability gradually began to significantly decrease with the elevation of the concentration of paracetamol in a dose-dependent manner. Paracetamol doses of $0.5 \mathrm{mg} / \mathrm{mL}, 1$ $\mathrm{mg} / \mathrm{mL}, 3 \mathrm{mg} / \mathrm{mL}$, and $5 \mathrm{mg} / \mathrm{mL}$ led to a $14 \%, 27 \%, 48 \%$, and $56 \%$ decrease in cell viability, respectively (Figure 1A).

Cell incubation for $48 \mathrm{~h}$ with a dose of $0.5 \mathrm{mg} / \mathrm{mL}$ paracetamol decreased the cell proliferation by approximately $31 \%$ compared to the control, similar to a 24-h incubation. With doses of 1,3 , and $5 \mathrm{mg} / \mathrm{mL}$, the level of decrease in proliferation was increased in a dose-dependent manner $(51 \%, 75 \%$, and $84 \%$, respectively) (Figure 1B).

The incubation of cells with a dose of $0.5 \mathrm{mg} / \mathrm{mL}$ paracetamol for $72 \mathrm{~h}$ decreased cell proliferation by approximately $37 \%$ compared to the control. With doses of 1,3 and $5 \mathrm{mg} / \mathrm{mL}$, this decrease in proliferation was increased in a dose-dependent manner (76\%, 83\%, and 87\%, respectively) (Figure 1C).

\section{The Effect of Paracetamol on Procaspase 3, Cleaved Caspase 3 and Bax Expression}

We observed a $40 \%$ increase in procaspase 3 expression after treatment with $0.5 \mathrm{mg} / \mathrm{mL}$ paracetamol compared to the control group. However, after treatment with $1 \mathrm{mg} / \mathrm{mL}$ paracetamol, the procaspase 3 expression did not elevate significantly compared to treatment with $0.5 \mathrm{mg} / \mathrm{mL}$ paracetamol, and a $20 \%$ increase in procaspase 3 expression was detected compared to the control group. The expression of Bax also increased by approximately $21 \%$ with $0.5 \mathrm{mg} / \mathrm{mL}$ paracetamol compared to the control group. However, after treatment with $1 \mathrm{mg} / \mathrm{mL}$ paracetamol, the Bax expression increased by approximately $17 \%$ compared to the control group. Cleaved caspase 3 level increased at the dose of $0.5 \mathrm{mg} / \mathrm{mL}$ was around $60 \%$ but at a dose of $1 \mathrm{mg} / \mathrm{mL}$, it is increased approximately twice as compared to the control (Figure 2).

\section{The Effect of Paracetamol on Cyclin B Expression}

The expression level of cyclin B decreased by $52 \%$ with treatment of $0.5 \mathrm{mg} / \mathrm{mL}$ paracetamol compared to the control group and its expression decreased in a dose-dependent manner (1 mg/mL, 58\%) (Figure 2).

\section{The Effect of Paracetamol on COX-2 Levels}

With a dose of $0.5 \mathrm{mg} / \mathrm{mL}$ paracetamol, the COX-2 level was reduced by approximately $36 \%$, dose of $1 \mathrm{mg} / \mathrm{mL}$ paracetamol, the COX-2 level was reduced by approximately $43 \%$ (Figure 2). 

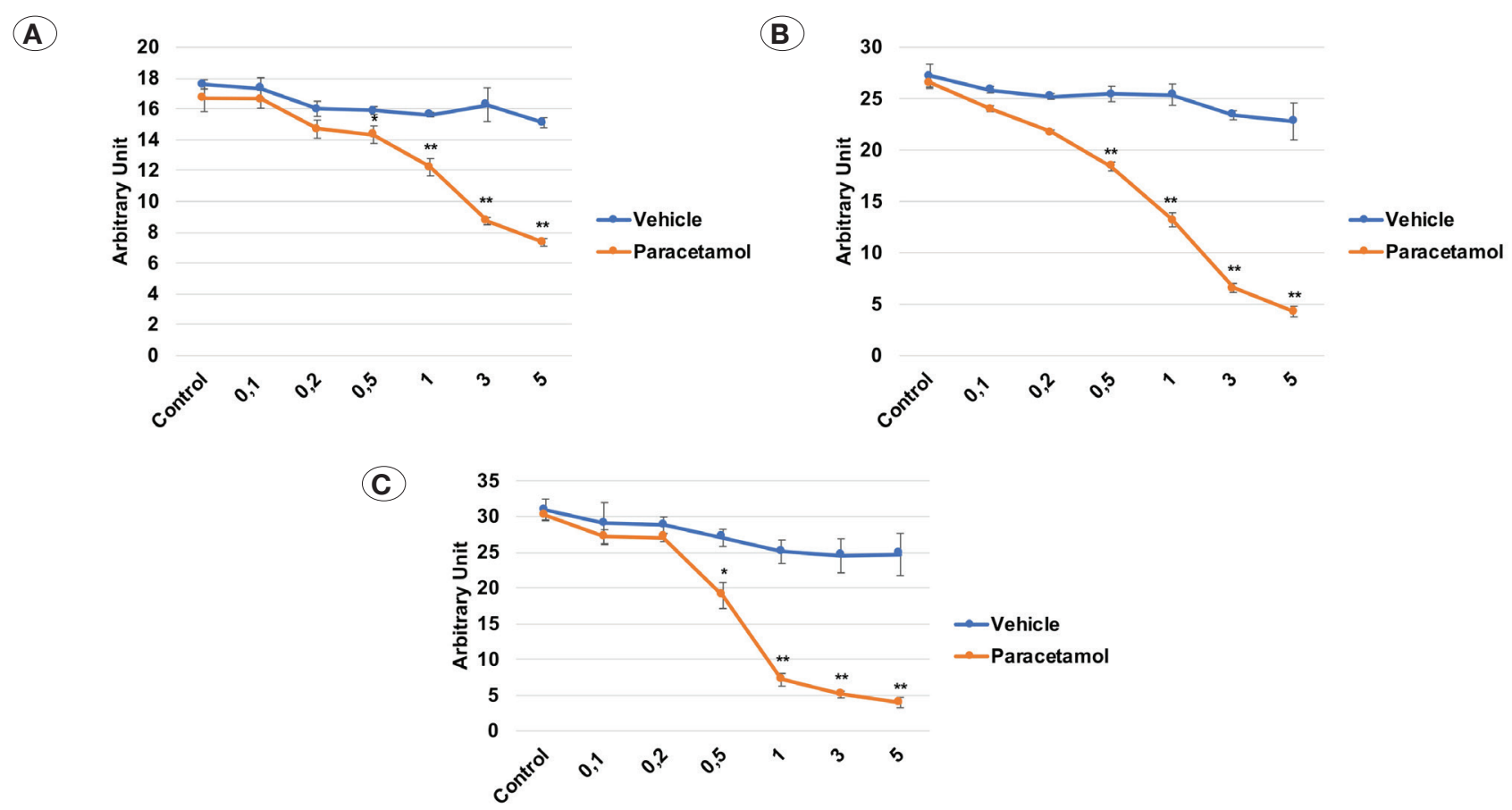

Figure 1: Effects of different concentrations of paracetamol against $A 172$ glioblastoma cell viability $\left({ }^{*} p<0.05,{ }^{* *} p<0.01\right)$ A) percent of cell viability of A172 glioblastoma cells after 24-h treatment with paracetamol B) percent of cell viability of A172 glioblastoma cells after 48 -h treatment with paracetamol C) percent of cell viability of A172 glioblastoma cells after 72-h treatment with paracetamol.

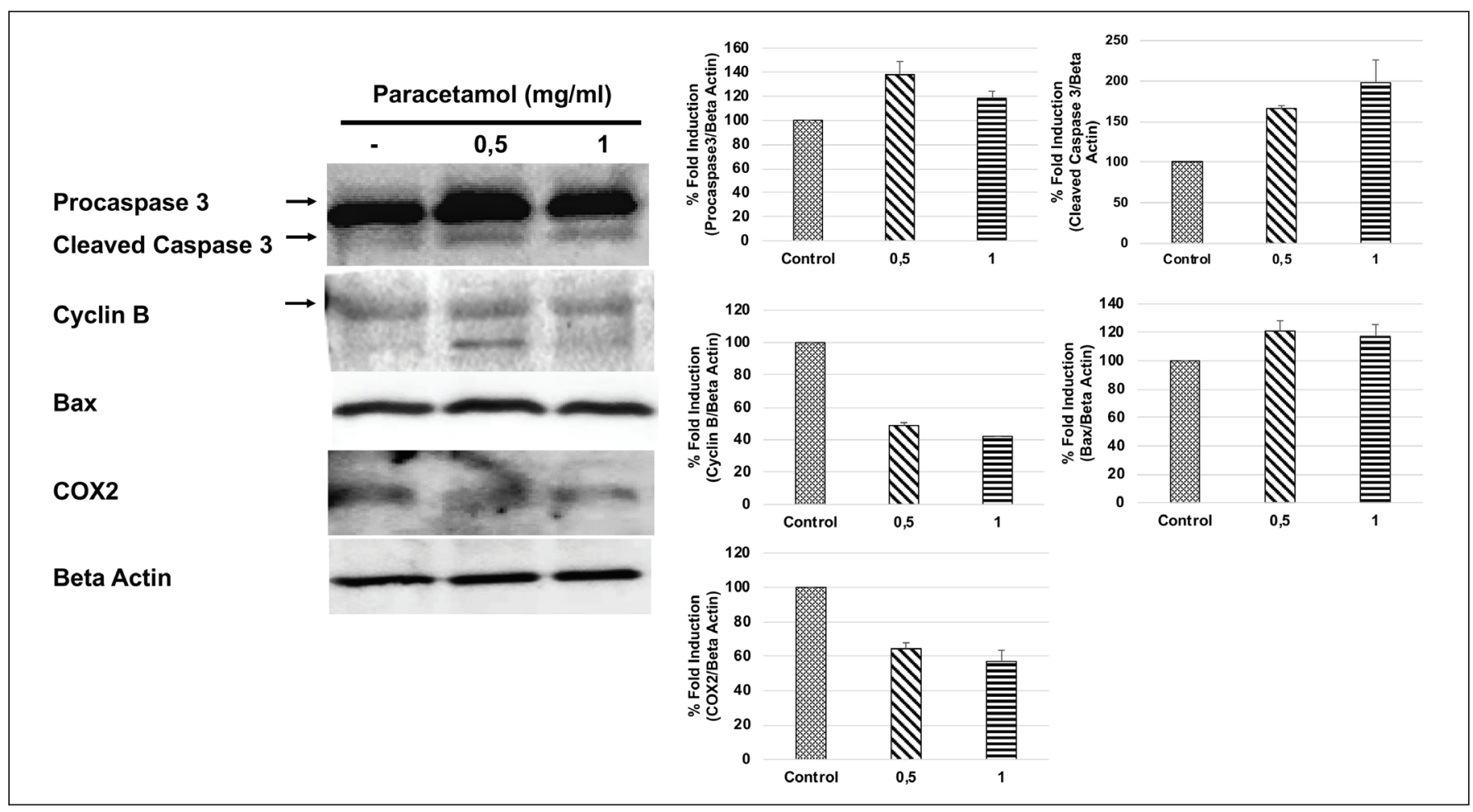

Figure 2: Paracetamol induced apoptosis and inhibited cell cycle. Procaspase 3 increased with different concentrations of paracetamol after 24-h treatment. Cleaved caspase 3 increased with different concentrations of paracetamol after 24-h treatment. Cyclin B inhibited with different concentrations of paracetamol after 24-h treatment. Bax increased with different concentrations of paracetamol after 24-h treatment. COX-2 inhibited with different concentrations of paracetamol after 24-h treatment. 


\section{DISCUSSION}

In this study, we investigated the effects of paracetamol on A172 glioblastoma cells and found increasing apoptosis and decreasing cell proliferation, as well as decreasing cyclin B and COX-2 with a dose of $0.5 \mathrm{mg} / \mathrm{mL}$.

Although paracetamol was initially classified as NSAID because it inhibited the COX enzyme and its products such as NSAIDs but it has been found that there is almost no anti-inflammatory effect in recent years. Paracetamol homogeneously distributes throughout the central nervous system (CNS) across the blood brain barrier. Therefore, it has been suggested that paracetamol exhibits analgesic and antipyretic activity by inhibiting central COX enzyme and no effect on peripheral COX enzyme. Again, several studies have shown that COX enzyme is more effective on peroxidase activity than catalytic activity and this peroxidase activity is much more in the CNS than the peripheral tissues (5). Similarly, in vivo study, paracetamol was found to reduce lipopolysaccharide-induced fever by inhibiting COX-2 in CNS (21). However, in contrast to these studies that on various CNS tumors such as neuroblastoma have shown that paracetamol causes toxicity in cells by reducing the level of glutathione, which has no effect on COX enzyme (19). In this sense, in our previous in vivo study with rat C6 glioblastoma cells, we found that there was no effect on COX2 enzyme as in the above study. In our study, there was no difference between COX-1 and COX-2 enzyme levels between tumor tissue and normal brain tissue, but the COX-3 enzyme was high in the tumor tissue and paracetamol significantly decreased the COX-3 enzyme. Paracetamol significantly decreased the tumor size compared to the control group (16). These results supported studies where paracetamol and other NSAIDs could cause tumor inhibition independently of COX2. However, paracetamol significantly decreased the COX-2 enzyme by direct proliferation in this study, which was dosedependent $(0.5 \mathrm{mg} / \mathrm{mL}, 1 \mathrm{mg} / \mathrm{mL}, 36 \%, 43 \%$, respectively). The difference between this study and the results we found in other studies may have resulted from the difference between in vivo and in vitro experiments, in vivo distribution and the metabolism of the drugs, cell line differences, and experimental techniques. The results of our study indicated that COX-2 inhibition has an important role in the anticancer properties of paracetamol. However, it should be considered that the COX-2 enzyme and many different mechanisms may have played a role, and more extensive studies are needed to clarify this issue.

Paracetamol in vitro studies have been shown to increase apoptosis in many cancer cell lines through many different mechanisms. For instance, studies with human neuroblastoma cells were shown to increase apoptosis over caspase 3 by activating Bax (14). In another study with neuroblastoma cells, paracetamol, NFkB p65, and IL1B activation resulted in an increase in Bax that lead to cell apoptosis over cytochrome c and caspase 3 (18). However, the same study with the U87 MG glioblastoma cell line differed from this study, which indicates that paracetamol causes grade III glioblastoma caspase 3 activation, although grade IV glioblastoma was shown to be highly resistant to the toxicity of paracetamol.
Similarly, different studies have shown that paracetamol causes apoptosis in cells due to cytochrome $c$ and caspase 3 activation in hepatic and lymphocyte cell lines (4). In addition to the increased apoptosis of paracetamol, studies have shown that paracetamol increases its metabolism into $\mathrm{N}$-acetyl-pbenzoquinonimine (NAPQI) and increases apoptosis in cells by causing mitochondrial damage (15). In our study, paracetamol caused an increase in procapase 3, cleaved caspase 3 and Bax protein, increased apoptosis in a similar manner as the above studies. The increase with 0.5 $\mathrm{mg} / \mathrm{mL}$ paracetamol was especially significant, which was particularly effective on cell proliferation (procaspase $40 \%$, Bax 21\%). However, the increase in procaspase 3 and Bax with $1 \mathrm{mg} / \mathrm{mL}$ paracetamol was lower than with $0.5 \mathrm{mg} /$ $\mathrm{mL}$ (procaspase 18\%, Bax 17\%). However, unlike bax and procaspase 3 , the increase in cleaved caspase 3 level at the dose of $0.5 \mathrm{mg} / \mathrm{mL}$ was around $60 \%$ but at a dose of $1 \mathrm{mg} / \mathrm{mL}$, it increased approximately twice as compared to the control. These results show that paracetamol increases apoptosis depending on dose and has toxic effects on glioblastoma cells. Activation of only cleaved caspase 3 at high doses may be due to the presence of active intrinsic apoptotic pathway in low doses and activated intrinsic and extrinsic apoptotic pathways in high doses. It should also be kept in mind that the toxic metabolite NAPQI, which occurs in an amount as high as glutathione cannot detoxify at high doses, may have increased cleaved caspase 3 and consequently apoptosis by causing mitochondrial damage

Various experimental studies have indicated that NSAID has positive effects on proliferation cancer cells. For example, it has been found to reduce cell proliferation of drugs such as ibuprofen, paracetamol, aspirin and naproxen in prostatecancer cells (1). Similarly, selective COX-2 inhibitors, paracetamol, and aspirin have been shown to reduce cell proliferation in ovarian cancer cells (20). In a study conducted in 16 different ovarian cancer cell lines, paracetamol had an anti-proliferative effect on the whole cell line (6). In our previous study on the HeLa cervix cancer cell line, we found that paracetamol reduced cell proliferation dependent on the dose and duration (9). In this study, we found that paracetamol reduced cell proliferation in glioblastoma cells, which is consistent with previously published articles stating that paracetamol inhibits cell proliferation. The effective concentration of paracetamol was 0.5 at $\mathrm{mg} / \mathrm{mL}$. The decrease in proliferation was directly proportional to the dose and duration of incubation.

Cyclins provide the activation of cyclin-dependent kinases (CDK) that phosphorylate proteins, which promote cell cycle progression. Cyclin B plays an active role in the transition of cells from the G2 to M phase. Various studies have indicated that NSAIDs have an effect on the cell cycle. For example, studies have shown that ibuprofen inhibits the transition of the G1 to S phase on prostate cancer cells (1). Once again, indomethacin was found to inhibit cell proliferation by stopping the cells in the G0/G1 and G2/M phase by inhibiting cyclin B1 and cyclin D in glioma cells (2). In our study, it was shown for the first time that paracetamol inhibited the level of cyclin B depending on the dose and may be prevented the proliferation by keeping the cells in the $\mathrm{G} 2 / \mathrm{M}$ phase $(0.5 \mathrm{mg} / \mathrm{mL}, 1 \mathrm{mg} / \mathrm{mL}$, 
$52 \%, 58 \%$, respectively). These results show that paracetamol performs some of its cell proliferation inhibiting properties via cyclin B. However, further studies are needed to determine the stage at which paracetamol maintains the cell cycle and whether it has any effect on the different cyclins and other parameters that affect cell cycle.

\section{CONCLUSION}

The results of our study showed that paracetamol has an antitumoral effect on glioblastoma cells via many different mechanisms, such as COX-2 enzyme, apoptosis cascade and cell cycle.

\section{ACKNOWLEDGMENTS}

We would like to thank to Zihni Yigit Oksuz from University British Columbia for his contribution to the experimental procedure.

This work was supported by Van Yuzuncu Yil University Scientific research projects (T-705/30062005). We declared that there is no conflict of interest with funding situations.

\section{REFERENCES}

1. Andrews J, Djakiew D, Krygier S, Andrews P. Superior effectiveness of ibuprofen compared with other NSAIDs for reducing the survival of human prostate cancer cells. Cancer Chemother Pharmacol 50:277-84, 2002

2. Bernardi A, Frozza RL, Hoppe JB, Salbego C, Pohlmann AR, Battastini AM, Sílvia SG. The antiproliferative effect of indomethacin-loaded lipid-core nanocapsules in glioma cells is mediated by cell cycle regulation, differentiation, and the inhibition of survival pathways. Int $\mathrm{J}$ Nanomedicine 8:711, 2013

3. Boulares $\mathrm{AH}$, Ren TJ: Mechanism of acetaminopheninduced apoptosis in cultured cells: Roles of caspase-3, DNA fragmentation factor, and the $\mathrm{Ca} 2+$ and $\mathrm{Mg} 2+$ endonuclease DNAS1L3. Pharmacol Toxicol 94:19-29,2004

4. Boulares $A H$, Zoltoski AJ, Stoica BA, Cuvillier O, Smulson M: Acetaminophen induces a caspase-dependent and $\mathrm{Bcl}-\mathrm{XL}$ sensitive apoptosis in human hepatoma cells and lymphocytes. Pharmacol Toxicol 90:38-50, 2002

5. Courade JP, Besse D, Delchambre C, Hanoun N, Hamon M, Eschalier A, Caussade F, Cloarec A: Acetaminophen distribution in the rat central nervous system. Life Sci 69:14551464, 2001

6. Cristina RB, Mack NB, Denise KO, Russell BM, Lynya IT, Edward EP, William EG: Sensitivity of ovarian cancer cells to acetaminophen reveals biological pathways that affect patient survival. Mol Clin Oncol 4:399-404, 2016

7. Desai V, Jain A, Shaghaghi H, Summer R, Lai JC, Bhushan AJ: Combination of biochanin a and temozolomide impairs tumor growth by modulating cell metabolism in glioblastoma multiforme. Anticancer Res 39:57-66, 2019

8. Ghanem Cl, Perez MJ, Manautou JE, Mottino AD: Acetaminophen from liver to brain: New insights into drug pharmacological action and toxicity. Pharmacol Res 109:119131,2016
9. Gorgisen G, Gulacar IM, Oksuz E: Effect of Acetaminophen on viability of HeLa cells. Eastern J Med 24:53-56, 2019

10. Kang KB, Zhu C, Yong SK, Gao Q, Wong MC: Enhanced sensitivity of celecoxib in human glioblastoma cells: Induction of DNA damage leading to p53-dependent G 1 cell cycle arrest and autophagy. Mol Cancer 8:1-16, 2009

11. Kesari S: Understanding glioblastoma tumor biology: The potential to improve current diagnosis and treatments. Semin Oncol 38 Suppl 4:S2-10, 2011

12. Leidgens V, Seliger C, Jachnik B, Welz T, Leukel P, VollmannZwerenz A, Ulrich B, Marina K, Oliver MG, Peter H: Ibuprofen and diclofenac restrict migration and proliferation of human glioma cells by distinct molecular mechanisms. Plos One 10:1-23, 2015

13. Li J, Chen X, Dong X, Xu Z, Jiang H, Sun X, Xueying SU: Specific COX-2 inhibitor, meloxicam, suppresses proliferation and induces apoptosis in human HepG2 hepatocellular carcinoma cells. J gastroenterol Hepatol 21:1814-1820, 2006

14. McPake CR, Tillman DM, Poquette CA, George EO, Houghton JA, Harris LC: Bax is an important determinant of chemosensitivity in pediatric tumor cell lines independent of Bcl-2 expression and p53 status. Pharmacol Toxicol 10:235-244, 1998

15. Moyer AM, Fridley BL, Jenkins GD, Batzler AJ, Pelleymounter LL, Kalari KR, Yuan J, Yubo C, Kendra K, Nordgren S, Richard MW: Acetaminophen-NAPQI hepatotoxicity: A cell line model system genome-wide association study. Toxicol Sci 120:3341, 2010

16. Oksuz E, Atalar F, Tanırverdi G, Bilir A, Shahzadi A, Yazici Z: Therapeutic potential of cyclooxygenase-3 inhibitors in the management of glioblastoma. J Neurooncol 126:271-278, 2016

17. Oksuz E, Bugday MS: Can intravesical application of paracetamol benefit the chemotherapy treatment of bladder cancer. Medical Hypotheses 131:1-3, 2019

18. Posadas I, Santos P, Ceña V: Acetaminophen induces human neuroblastoma cell death through NFKB activation Plos One 7:1-13, 2012

19. Posadas I, Vellecco V, Santos P, Prieto-Lloret J, Cena V: Acetaminophen potentiates staurosporine-induced death in a human neuroblastoma cell line. Br J Pharmacol 150:577-585, 2007

20. Rodríguez-Burford C, Barnes MN, Oelschlager DK, Myers RB, Talley LI, Partridge EE: Effects of nonsteroidal antiinflammatory agents (NSAIDs) on ovarian carcinoma cell lines: Preclinical evaluation of NSAIDs as chemopreventive agents. Clinical Cancer Research 8:202-209, 2002

21. Ruud LE, Wilhelms DB, Eskilsson A, Vasilache AM, Elander L, Engblom D, Anders B: Acetaminophen reduces lipopolysaccharide-induced fever by inhibiting cyclooxygenase-2. NeuroPharmacology 71:124-129,2013

22. Sheng $\mathrm{H}$, Shao J, Morrow JD, Beauchamp RD, DuBois $\mathrm{R}$ : Modulation of apoptosis and $\mathrm{Bcl}-2$ expression by prostaglandin E2 in human colon cancer cells. Cancer Res 58:362-366, 1998

23. Sobolewski C, Cerella C, Dicato M, Ghibelli L, Diederich M: The role of cyclooxygenase-2 in cell proliferation and cell death in human malignancies. Int J Cell Biol 2010:1-21, 2010

24. Yiang GT, Yu YL, Lin KT, Chen JN, Chang WJ, Wei CW: Acetaminophen induces $\mathrm{JNK} / \mathrm{p} 38$ signaling and activates the caspase-9-3-dependent cell death pathway in human mesenchymal stem cells. Int J Mol Med 36:485-492, 2015 